\title{
THE DESPERATION OF FATHER IN GREAT DEPRESSION ERA AS SEEN IN ARTHUR MILLER'S THE DEATH OF SALESMAN
}

\author{
SRI MEGAWATI ${ }^{1}$ \\ RAFLIS $^{2}$ \\ FETRI RENI ${ }^{3}$
}

\author{
Volume 1 Nomor 1 \\ JILP \\ ISSN: 2581-0804 \\ E-ISSN: 2581-1819
}

\begin{abstract}
The title of this thesis is an analysis of the ambitions and dreams of Americans in the 1920 s, focusing on the analysis of a leading figure from the circle An ordinary person named Willy Loman who turned his career into a businessman (Salesman), but eventually found failure and experienced severe frustration and eventually committed suicide by crashing the car fence home.

Problems in this thesis is a problem associated with characterizations such as Willy Loman has an inner conflict between his two children Biff and Happy. In this thesis, the author uses a psychological approach. This approach

saw the development of characters in literary works that are a reflection of the true human psyche. This approach also explains the character changes in the main characters.

The purpose of this study is for the reader to know the ambitions and dreams of what is in the drama of the death of Salesman, and the results obtained from this analysis is that material satisfaction greatly affects the lives of Americans especially Willy loman, the main character in this drama he Very ambitious to achieve material satisfaction such as home, money, success, wealth, honor, equality of rights so that people around him will put respect and sympathy.
\end{abstract}

\section{Keywords: Desperation,Failure, Death}

\begin{abstract}
Judul skripsi ini adalah The desperation of father in great depression era as seen in Arthur miller's The death of salesman skripsi ini merupakan analisis tentang ambisi dan mimpi orang-orang Amerika pada sekitar tahun 1920an, yang memusatkan pada analisis mengenai seorang tokoh utama dari kalangan orang biasa bernama willy loman yang merubah karier hidupnya menjadi pebisnis (Salesman), tetapi akhirnya menemui kegagalan dan mengalami frustasi berat dan akhirnya melakukan bunuh diri dengan menabrakan mobil kepagar rumah.
\end{abstract}

ABSTRAK

Permasalahan dalam skripsi ini adalah masalah yang berhubungan dengan penokohan seperti Willy Loman mempunyai konflik batin antara dua anaknya Biff dan Happy. Dalam skripsi ini, penulis menggunakan pendekatan kejiwaan. Pedekatan ini melihat perkembangan tokoh Adalam karya sastra yang merupakan cerminan dari kejiwaan manusia yang sesungguhnya. Pendekatan ini juga menjelaskan perubahan

karakter pada tokoh utama.

Tujuan dari penelitian ini adalah agar 
pembaca dapat mengetahui ambisi-ambisi dan mimpi apasaja yang terdapat pada drama the death of Salesman, dan hasil yang diperoleh dari analisis ini adalah bahwa kepuasan materi sangat mempengaruhi kehidupan orang Amerika terutama Willy loman, tokoh utama dalam drama

Kata kunci: keputusasaan, kegagalan, kematian.

\begin{abstract}
ini dia sangat berambisi untuk mencapai kepuasan materi seperti rumah, uang, kesuksesan, kekayaan, kehormatan, persamaan hak sehingga orang-orang di sekitarnya akan menaruh rasa hormat dan simpati.
\end{abstract}

\section{BACKGROUND OF THE PROBLEM}

Drama is one of the literary works are filled with dialogues and performed on stage. As one of the literary works are staged, then in the play always refers to a play that has been prepared. Writing a play is usually taken through real events that originated from human life and fictional events that are based on the author's imagination. Play wright usually written in dialogue form and staged by actors with the aim of describing the incidence of life through the disputes and conflicts that occur on stage.

In this thesis, the writer uses Arthur Miller's play the death of salesman. This play is about Willy Loman who tries to reach the American dream. In this play. Willy as the leading character lives all the that of his life trying to become a successful, famous and rich salesman.Even his self image that he potrays to the others is a lie and is a even able to deceive himself with it the tries to life in America dream. and This play also shows his family encounters many problems and many problem that happening this story the result of America Dream. Many of Willy's problem are self inflicted are because he wants to live in the America Dream.

In analyzing the topic, the Death of Salesman Willy loman character experiencing severe frustation causes three things: has inner conflict with his son Biff and Happy, both felt facing problems with his boss and the three he already felling fatigued or fail in business.

\section{METHOD OF RESEARCH}

In this research method is instrinsic and extrinsic side, which try to explain about characters, tema, plot, point of view and the extrinsic side that becomes that analysis in the writing, it is an attempt to interpret literature in the blight of its social context and its incident, in most cases as psychology, biography, society, history, social and ideas.

In analyzing The death of Salesman the author uses a psychological approach, As the writer has mentioned before, the scientific approach that is used in this analysis is psychological approach. This method is applied in systematic procedures, which are mainly to collect the psychology material as the basic study to analyze the Drama the death of Salesman.

\subsection{Method of Collecting Data}

In method collecting the data, the writer uses library research. This research is oriented in the

library in order to find the related the title analyzing in the thesis, primary data and condary data. However it is not restricted in finding other written material from internet or even from the motion picture. According to Pradopo (2001:23), penelitian pustaka merujuk kepada observasi yang di lakukan dalam pustaka, di mana penulis memperoleh data dan informasi tentang suatu objek dalam sebuah buku.

Library research refers to the observation that is executed in the library, which the writer gains the data and information about his object through the books.(translated by writer)

A library is a collection of sources of information. It provides physical or digital access to material, and may be a physical building or room, or a virtual space, or both. A library's collection can include books, periodicals, manuscripts, films, maps, prints, documents, 
microform, CDs, cassettes, videotapes, DVDs, Blue-ray Discs, e-books, audio books, databases, and other formats.

Activity of data collection is a very important part in any form of research.In this study, the writer uses documentation. The method of documentation is to find data about the things or variables.The instrument of this study is the writer. The writer is as the key or main instrument that spent a deal great or time reading and understanding the Drama.

2.2 Method of Analyzing Data

In method analyzing the data, the information from data collection is processed and presented in form of thesis. In the application, the writer uses dynamic structuralism method.

Struktur dinamik adalah pendekatan umum untuk mengembangkan beberapa struktur yang berehubungan dengan psikologi dan di bangun olehnya sendiri seperti stuktur dinamik, kemampuan yang di miliki masyarakat (tindakan dan pikiran). Kerangka ini, alatnya menerapkan dua istilah yakni mengembangkanistilah panjang dan memperluas istilah pendek (membangun struktur dinamik dan kemampuan), perubahan kaidah ini, sekaligus fokus pada perubahan dan stabilitas (Pradopo, 2001:69).

Dynamic structuralism is ageneral approach to development that views psychological structure as the dynamic organization of selfconstructed, socially embedded skills and activities (actions and thoughts): This framework, and its tools, applies to both long-term development and short-term micro development (buildingof dynamic structures and skills), Variability is the norm, not the exception, focuses simultaneously on variability and stability (Pradopo, 2001:69).

\section{RESEARCH FINDING}

In this chapter, the writer shows the problem that happen for the drama seperate in two elements that can be seen, which are instrinsic and extrinsic side. From the instrinsic side, Willy failure to recognize the love that was offered to him only an inner torment. Willy in
Etymologically, structure came from word, structura (Latin), means form or building. Structuralism is an understanding of elements of the structure itself with mechanism of interrelation, the interrelation of one element with the others, and the interrelation of one element with the totality. Definitively, structuralism gives attention to the analysis of elements in literary works. The elements of Drama are theme, conflict, setting, characters, plot,etc

\subsection{Technique for Collecting the \\ Data}

The technique of collecting the data in this research is library research; the data from both primary and secondary sources are collected and recorded in a short of document as evidence. The techniques of collecting data are as follows:

a. Reading the novel,

b. Browsing the internet to get several information and related to the subject of the study,

c. Taking notes of important data from both primary and secondary sources,

d. Arranging the data into several parts according to its classification,

e. Selecting particular part that are considered important and relevant for the analysis.

2.4

echnique for Analyzing

the Data

In the procedure of analyzing the data, the writer collects various books in order to support his analysis. The writer collects books on literature and dealing human emotions. In order to fully understand the contents of the drama. Interpretation is done after he completely understands it and then he tries to analysis it. In analysis the novel, the writer first reads a book on how analysis fiction and some other books concerning the understanding of the elements of literature.

mind, the lack of self knowledge that he possesses, make him to achieve tangible results of all the lack of his success. In all her mind, nothing can happen. And finally she was trying to commit suicide. In this way he was the one to end it all. Suicide in her own home, precisely in 
the kitchen, using gas cylinders are removed and she locked herself in it.

At least, from the extrensic side that becomes that analysis in the writing, it is an attempt to interpret literature in the blight of its social context and its incident, in most cases as psychology, biography, society, history, social and ideas

4.1 The Causes of the Character's Depression in the Death of Salesman

The real drama script is its own setting of short duration since Loman experiencing short duration since willy loman suffered severe frustration. however, the technique flasback (flashback), the drama becomes long. flashback technique in use arhur miller aims to lead the reader to the circumstances or situations that make the character willy loman the end of his conduct despair and suicide by crashing his car.

Flashback Behind character Willy Loman who experience frustration weight in a play Salesman work Arthur Miller the death of a Salesman due to three factors, namely:

(1) Willy have conflicts inner with his son Biff da Happy

(2) Willy was facing new problems with his boss, he is less able to meet the desire of business outlined the company was replaced by that already happened to be his boss the boss (howard Wagner) young,

(3) Willy feel jaded and failed in business will fail and he thought he would not be able to again generate income sufficient for family. because heavy frustrating Willy Loman, which initially respected family (especially by children)he has a steady job, chose to commit suicide by crashing his car so that he died the World to house building.

Willy Loman experiencing inner conflict with his son Biff and happy because at first Willy loman always require children to be successful, hardworking and high-income and highly respected people in the community. Willy Loman always indoctrinate that one of those exemplary is himself, Willy loman always say that he is a successful man, a hard worker respected, both in terms of moral, wealth and skill. as a father who set farmers or craftsmen and then reinvent itself as a business person (Salesman or marketer), he managed to buy a house in the suburbs of New York, have a car, have a lot of money, and have a beautiful wife, skilled and sympathetic named linda.
At first, his two sons (Biff and Happy) do feel salute to his father who was exemplary, but at the next level both of these children end up losing the sympathy and even hate .Biff (first child) even get to the motivation of his father began to rebel because 3 reasons:

1). He (Biff) is often said to be a slacker (a lazy worker) because he could not follow the rhythm of work New England who became an idol of his father. 2). He (Biff) is not willing to follow the advice of his father to become a frontier man who dared to emigrate to the western part Amerika States to later find out that his father (Willy) conducted an affair with another woman (the women from Boston) when business.

3). Make Biff hated his father and then he is not willing to listen to the advice of his father, Biff hatred that culminated when he saw his father's business began to deteriorate and his father began to experience financial difficulties.

In mind Biff (including his brother Happy), his father failed to serve as examples, both in terms of career, in terms of loyalty, as well as in terms of financial management. (Linda) is the most beautiful woman, sympathetic, loyal and compassionate in their pastures father (Willy) acted arbitrarily and great sin against his wife:

To happy, linda represents the type of admirable women he would willingly marry, as contrasted with the girls of easy virtue with whom he regularly has affairs. His mother has high standards and incorrutible. To Biff,however, Linda appears the victim of willy's boorish, in considerate action. He is incensed that she should have to listen to his father's wild out bursts.Linda, therefore, is viewed in this scene, the ideal wife and mother to be shielded, if pos sible from the gracelesss behavior of willy (Nourse, 1993:25).

factor seems inner conflict with his son (Biff and Happy) which leads to the loss of her confidence to her that makes Willy loman become frustrated or depressed. he felt the loss of "face" in front of her children. like a chess player, Willy loman "dead measures" and psychologically he has experienced (death) before he committed with his car crashed into a fence. 
When Willy loman was young, he entered the Company wagner (the Wagner company) as a salesman in the language of modern business is often referred to as a marketer or a "marketing expert" under the leadership of "Boss" named Wagner (old), she was very happy because he has the creativity and expertise in business, and Wagner gives confidence and praise as a Salesman who is rightly called the "prince" expert "(a prince was Masterful).

At first, Willy Loman was assigned to open a business in New England (states of the northeast United States) and he managed to "control" of the business in the region. therefore, Willy loman is able to earn a lot of money as well as experience in both business and in other fields.

However, the business outlook has been done by Willy loman Salesman undergone significant changes are:

(1). The head of the company (the Wagner company) was replaced by Howard (son Wagner) that has character and a different business paradigms,

(2). The modern business environment demands a tough competition "silence" (coldness), and system (system, impersonal tone), and

(3). The rhythm of work and business appetites Howard (young) is different to that of Willy loman (which has begun to ripen). some of it is perceived as a burden or a big problem for Willy loman.

Willy loman who can not follow the rhythm of modern business which is full of competition and new paradigm began to experience financial difficulties. the cause is decreased by an income and expenditure remains much. moreover he had an affair with a woman in the city of Boston (in New York, and to get there takes a long time and quite a lot of pocket money, though, the company's marketing konstrasi The Wagner Company is no longer concentrated in New England.

Another factor that led to willy loman businesses fail is age itself: Willy who has begun to ripen into not agile or sekkreatif first. he became more like marah0 temper (outbursts), especially if they are at home. moreover, he was at home feeling estranged (alienated) uncomfortable (in convinient), hated or despised (hatred), and the loss of love and trust (loss of love and faith). that feel heavy psychological condition that makes it day dreaming or nostalgic, create morale decreases and even the spirit of life lost.

Nourse (1993: 24) provides for the conclusion of Willy loman following conditions:

The tone of the play is often nostalgic. Here Willy looks back to better times when old wagner was his Boss and his house had a flourishing garden. He recalls how much admired the ligh-hearted Biff was aboy and how beautidful the red Chevrolet looked when polished. The present, by contrast, is a time and bewilderment, of blighted hopes and bitter quarrels ( Nourse, 1993:24).

4.2 Willy Loman have a Conflict with his two Children, Biff and Happy

When their two dreams collide, it becomes frustrating to Willy because he believes that his way is the right way. If a father becomes too involved in his son's life, Miller believes friction will be the resultant factor. As unfortunate as it is, there are many instances where a father favors one son over another, which leads to social conflicts within the lessfavored son. In most cases it is the oldest son that is being favored while the younger son is ignored.

Usually the father doesn't even realize what is happening. He simply gets too caught up in the successes of his eldest son and he may even try to live out his life through his son's experiences. because Willy has dreams of grandeur for Biff, Miller subtly shows how Happy is over looked.

Throughout the novel, Willy makes references to how wonderful Biff. You got greatness in you, Biff You got all kinds of greatness. Happy, however, is barely talked to. This kind of favoritism has a profound effect on a child. In order to be acknowledged by his father, Happy believes that he must become Willy's version of a success by acquiring wealth and being popular. He convinces himself that this is the only way he'll ever be truly happy. In the end though, he realizes that he is not happy. It's what I always wanted. My own apartment, a car, and plenty of women. And still, goddammit, I'm lonely. Happy has been living his entire life in a way that he believes will bring him attention from his father, yet he becomes more miserable than if he had gone his own way.

When a father chooses to look favorably upon 
one son over another, disharmony occurs in the father-son relationship as well as in the son's life. Within a father-son relationship, it is the responsibility of the father to provide sound values and leadership for his sons. In almost every family, the sons will look to their father as a role model and a hero. It is in the father's best interest to use this opportunity to instill qualities that will allow his sons to become responsible individuals.

Miller uses the Loman family to show how a father acts when he is more concerned with appearance than anything else. Willy is obsessed with popularity. He believes that if a person is popular, he has everything. Since Willy was never popular himself, he adores the fact that his sons, and Biff in particular, are. In a sense, Willy idolizes his children more than they idolize him. Because Willy sees that his boys have attained what he deems as important, he forgets to teach them moral values.

4.3 Socio-cultural Aspects (Cultural) for the Story of the Death of a Salesman.

Arthur Miller seem to want to give a message that the culture of the American dream that is important but what happens is the family Willy failure. Willy 'worked hard to achieve success in the economy but he "slipped" while his two sons did not do as what is outlined by the American dream, In the culture of America, the American dream, in American culture, the American Dream is a belief that teaches that one can achieve success (better living) through hard work, courage and confidence are strong, as explained below:

The american dream is the faith held by many in the united states of America that through hard work, courage, and determination one can achieve a better life for oneself, usually through financial prosperity. Thhese were values held by many early European settlers, and been passed on to subsequent generations. What the American dream has become is a question under constant discussion, and some believe that it has led to an emphasis on material wealth as measure of success and/or happiness.

other socio-cultural clash is the gap between the state of the past with the present (currently experiencing difficulties willy). Willy Loman is often reminisce about many things including home and home environment is very conducive in the past. the house has been "besieged" by tall buildings and luxury apartments, which symbolizes the "kesumpekan" (high density) and a threat to kebagiaan family. for American society, especially those who follow abab -19 romanticism culture tends to yearn to be able to stay at home is still surrounded by a courtyard with plants and trees.

Other socio-cultural conflict is that willy implement the New England puritan culture of hard-working, creative, saving, and are concerned for their children, but they do not want melkukannya because they want something tasty, easy, practical and pragmatic. Sociologically, the drama script has been photographing the reality in the United States as in explain the Encyclopedia Wikipedia:

Since the end of world war II, young american families have sought to live in relative comfort and stability in the suburbs that were built up around major cities. This led to the rise of the relatively conservative 1950s, when many pursued the " perfect family" as a part or consequence of the American Dream. This period was shattered by a new generation of young people who embraced this hippie values of the 1960s, denying traditional values such as the American Dream.

Through his work Death of a salesman. arthur miller wants to give the allusion to "the loss of work ethic and moral values of the American people on gerasi young. insinuation that becomes stronger as Willy loman himself also having an affair with a woman in Boston which resulted in (1) further hlang trust their children to figure willy and (2) the more shaky the family unit both in terms of psychological, economic, or social, the only way that diciptakn by the author to "terminate" the heavy burden the main character (Willy) is the death of death, and the author creates the death of Willy how menabrakan yourself with a car with a family destination willy will get an insurance policy.

Willy Loman death with various aspects: (1) The psychological aspect is the conflict unresolved (2) the economic aspect is to bring to an outstanding debts and obtain an insurance policy and (3) The cultural aspects that portray a conflict of values within society or character and ends with death, either naturally or by suicide (as do ernest hemigway who never won the Nobel in literature). 
IV CONCLUSION AND SUGGESTION

Death of a salesman plays by Arthur miller Proven very interesting to read the reviews. The play presents the theme is interesting to review examined:

(1) Willy Loman Its role as the protagonist that at the beginning of Success, different aspects and finally chose suicide

(2) Biff (first child Willy) The initially Very Respectfully And to placate And the advice of his father, but later revolted and hostile,

(3) Happy (the second son Willy) who prefers dissipate and play scandal because he had caught her father affair, and

(4) Linda (Willy's wife) who played the Panion of the protagonist with the characteristics of a good so he deserves to be considered as an exemplary wife and mother at home Willy loman.

besides, the drama script also contains symbols and moral values such as the need exemplary, hard working, creative nature, honesty, frugality, and moral. Plays this too provide examples tragedy that may happen in other families because of factors such as too ambitious as a person's ideals. immorality, business, the danger of modernization and business and economic competition a large city like New York.

\subsection{Suggestion}

The writer hopes this thesis analysis may at least add the vocabulary of literary study in which may be useful for students of literature later on. That is why this thesis analysis is open for further study its weakness. However, the analysis it offers has given the notion that is better to try than to do nothing. The writer hopes this thesis may encourage students of literature to make vigorous research in literary works. 


\section{Bibliography}

Hall,Calvin s. 1979. A Primer Of Freudian Psychology. New York: Nal Penguin Inc.

High, Peter, 1988. An Outline Of American Literature. USA: Longman Group Limited.

Daiches, David.1990. Critical Approaches to Literature, singapore: singapore Publisher Ltd

Goldmann, Lucien, 1967. Genetic Structuralism in Sociology Of Literature.

Belgiun: Brussel University.

Harry A.S. 1967. Oxford Advanced leamer's Dictionary Of corrent english .Great Britain: Oxford University Press.

Lauther Paul (ed.). 1995. The Heath Anthology Of American Literature. Vol. I and II. Lexington messadhussetts: D.S Heath and Company.

Levin.Hany. 1973. "Literature as an Institution" in Elizabeth and Bums 1973. The
Sociological Perpetive. USA: Penguin Education.

Pradopo, Rachmat Djoko, et all. 2001. Metodologi Penelitian Sastra. Yogyakarta: PT. Hamindita Graha Widia.

McMichel, George (ed.). 1980. Anthology Of American Literature. Vol. I and II. Second Edition, New York: Mcmillan Publishing Co. Inc.

Miller, Arthur. 1963. The Crucible. New York: The Viking Press.

Nourse, Joan Telluson. 1965. Arthur Miller's Death Of Salesman and All My Son. New York: Simson and Schuster Inc.

Stradney, James, 1990. Sigmund Freud: The Interpretation Of Dreams. New York: Avan Books.

Wellek, Rene and Austin Warren. 1956. Theory Of Literature. New York: Hartoourt Brace and World Inc. 